\title{
Implementasi Worksheet ELPSA Pada Pembelajaran Relasi Rekurensi
}

\author{
Andhika Ayu Wulandari \\ Program Studi Pendidikan Matematika, Universitas Veteran Bangun Nusantara \\ E-mail: dhika.math@yahoo.co.id
}

\begin{abstract}
Abstrak
Relasi rekurensi adalah salah satu materi dalam perkuliahan Matematika Diskrit yang penggunaannya dalam kehidupan sehari-hari cukup beragam. Akan tetapi, berdasarkan angket respon mahasiswa pada Tahun Akademik 2015/2016, sebanyak 50,74\% mahasiswa belum memahami materi yang diberikan dan $42,65 \%$ mahasiswa tidak menyukai metode ceramah yang selama ini digunakan selama perkuliahan. Oleh karena itu, diperlukan suatu model pembelajaran dan media yang dapat mendorong mahasiswa untuk disiplin dalam berpikir dengan perhitungan, analisis dan logika yang dimiliki. Worksheet ELPSA adalah suatu lembar kerja berbasis model ELPSA (experience, language, picture, symbol, application) yang diharapkan dapat menjadi alternatif dalam pembelajaran relasi rekurensi. Tujuan dari penelitian ini adalah untuk mengetahui rata-rata kemampuan pemahaman mahasiswa dalam pembelajaran relasi rekurensi menggunakan worksheet ELPSA melalui uji coba terbatas. Uji coba terbatas dilakukan pada mahasiswa VI.B Program Studi Pendidikan Matematika Universitas Veteran Bangun Nusantara Sukoharjo yang dipilih secara random dari 3 kelas yang ada. Worksheet ELPSA yang dikembangkan dan tes pemahaman materi relasi rekurensi dinilai kelayakannya oleh 2 validator sebelum digunakan. Data diketahui berasal dari populasi yang berdistribusi normal berdasarkan analisis dengan uji lilliefors. Dengan uji t pada tingkat signifikansi $5 \%$, diperoleh kesimpulan bahwa rata-rata nilai tes mahasiswa lebih besar dari 76. Hal ini berarti berdasarkan uji coba terbatas, penggunaan worksheet ELPSA dapat menghasilkan rata-rata pemahaman mahasiswa melebihi batas minimal yang ditetapkan Universitas untuk mendapatkan nilai memuaskan.
\end{abstract}

Kata Kunci : Worksheet; ELPSA, Kemampuan Pemahaman Mahasiswa

\section{Implementation of ELPSA Worksheets on Recurrence Relation Learning}

\begin{abstract}
Recurrence relations is one of the materials in Discrete Mathematics lectures whose use in everyday life is quite diverse. However, based on questionnaire of student responses in the academic year 2015/2016, as many as 50,74\% of students have not understood the material given and $42,65 \%$ of students did not like the method of lectures that have been used in lectures. Therefore, it needs a learning model and media that can encourage students to dicipline in thinking with calculation, analysis, and logic owned. ELPSA worksheet is a worksheet based on the ELPSA model (experience, language, picture, symbol, and application) which is expected to be an alternative in learning recurrence relation. The purpose of this research is to know the average ability of students understanding in kearning recurrence relation using ELPSA worksheet through a limited trial. Experiments conducted on IV B students of Mathematics Education Study Program of Veteran Bangun Nusantara Sukoharjo University selected randomly from 3 existing classes. The developed ELPSA worksheet and the comprehension test are judged to be eligible by 2 validators before use. Based on the prerequisite test of the study, it was concluded that the normal distributed data. With the $t$ test at 5\% significance level, it is conclude that the average test score of students is greater than 76 . This meas that based on a limited trial, the use of the ELPSA worksheet can result in an average of student's understanding exceeding the minimum limit set by the university to obtain a satisfactory value.
\end{abstract}

Keywords : Worksheet, ELPSA, Student's Understanding Ability 



\section{PENDAHULUAN}

Relasi rekurensi adalah salah satu materi dalam Matematika Diskrit yang banyak diaplikasikan dalam kehidupan sehari-hari terutama bidang perbankan dan asuransi. Mahasiswa Matematika/Pendidikan Matematika diharapkan dapat memahami materi ini sehingga dapat mengaplikasikannya setelah mempelajarinya. Untuk mencapai tujuan tersebut, maka dosen sebagai fasilitator harus dapat berinovasi dalam pembelajaran relasi rekurensi. Inovasi pembelajaran dapat dilakukan melalui pengembangan model pembelajaran maupun media yang digunakan dalam menyampaikan materi. Melalui pembelajaran yang inovatif dan dengan media yang menarik, diharapkan kemampuan mahasiswa dalam memahami relasi rekurensi dapat meningkat.

World Bank menyatakan bahwa penerapan pembelajaran yang berpusat pada guru (teacher centered) dan berpedoman pada buku teks adalah karakteristik pembelajaran yang sering terjadi di Indonesia, (Lowrie \& Patahuddin, 2015). Hal yang sama diungkapkan oleh Usman (2013) bahwa peserta didik lebih sering belajar matematika hanya dari penjelasan guru.

Perkuliahan matematika diskrit yang selama ini dilakukan dengan pembelajaran langsung belum memberikan hasil yang memuaskan. Hal ini didukung oleh data nilai mahasiswa semester VI Tahun Ajaran 2015/ 2016, hanya 37.09\% dari 124 mahasiswa yang mendapat nilai A atau B ( > 76) seperti pada gambar 1.

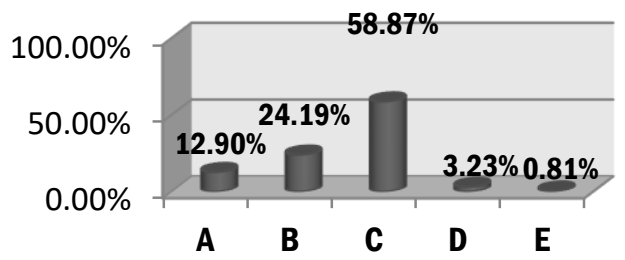

Gambar 1. Distribusi nilai Matematika Diskrit Tahun Akademik 2015/2016
Distribusi data nilai pada gambar 1 didukung oleh hasil angket respon mahasiswa terhadap perkuliahan relasi rekurensi yang ditunjukkan oleh tabel 1. Berdasarkan angket respon mahasiswa pada Tabel 1, hanya 49,26\% yang menyatakan mampu memahami materi yang telah diajarkan, dan hanya $25,76 \%$ yang dapat mengaplikasikannya dalam kehidupan sehari-hari. Oleh karena itu, dalam pembelajaran relasi rekurensi pada Tahun Akademik 2016/2017, peneliti sekaligus dosen pengampu Matematika Diskrit berupaya mencari alternatif solusi dari permasalahan tersebut. Salah satunya dengan mengembangkan suatu lembar kerja berbasis ELPSA (experience, language, picture, symbol, application) yang selanjutnya disebut dengan worksheet ELPSA.

Tabel 1. Angket Respon Mahasiswa Tahun Ajaran 2015/2016 Terhadap Perkuliahan Matematika Diskrit

\begin{tabular}{|c|c|c|}
\hline Indikator & Aspek & Persentase \\
\hline Tingkat & $\begin{array}{l}\text { Memahami materi } \\
\text { yang telah diajarkan }\end{array}$ & $49,26 \%$ \\
\hline $\begin{array}{l}\text { pemahaman } \\
\text { mahasiswa }\end{array}$ & $\begin{array}{l}\text { Mengetahui tujuan } \\
\text { mempelajari }\end{array}$ & $38,24 \%$ \\
\hline terhadap & Matematika Diskrit & \\
\hline $\begin{array}{l}\text { perkuliahan } \\
\text { Matematika }\end{array}$ & $\begin{array}{l}\text { Mampu } \\
\text { mengaplikasikan }\end{array}$ & \\
\hline Diskrit & materi kedalam & $25,16 \%$ \\
\hline $\begin{array}{l}\text { Faktor } \\
\text { penyebab } \\
\text { tingkat }\end{array}$ & $\begin{array}{lr}\begin{array}{l}\text { Menyukai } \\
\text { pembelajaran } \\
\text { digunakan }\end{array} & \text { yang } \\
\end{array}$ & $57,35 \%$ \\
\hline $\begin{array}{l}\text { pemahaman } \\
\text { yang }\end{array}$ & $\begin{array}{l}\text { Mudah mendapatkan } \\
\text { referensi }\end{array}$ & $77,21 \%$ \\
\hline $\begin{array}{l}\text { dimiliki } \\
\text { mahasiswa }\end{array}$ & $\begin{array}{l}\text { Materi yang diajarkan } \\
\text { terlalu sulit }\end{array}$ & $63,24 \%$ \\
\hline
\end{tabular}

Berdasarkan angket respon mahasiswa pada Tabel 1, hanya $49,26 \%$ yang menyatakan mampu memahami materi yang telah diajarkan, dan hanya $25,76 \%$ yang dapat mengaplikasikannya dalam kehidupan sehari-hari. Oleh karena itu, dalam pembelajaran relasi rekurensi pada Tahun Akademik 2016/2017, peneliti sekaligus 
dosen pengampu Matematika Diskrit berupaya mencari alternatif solusi dari permasalahan tersebut. Salah satunya dengan mengembangkan suatu lembar kerja berbasis ELPSA (experience, language, picture, symbol, application) yang selanjutnya disebut dengan worksheet ELPSA.

Lembar kerja dapat mengembangkan kemampuan berfikir siswa dan mendorong siswa melakukan praktikum untuk mengkonkritkan konsep (Zahro, 2017). Prastowo (2013) juga menyatakan bahwa fungsi dari lembar kerja diantaranya adalah sebagai bahan ajar yang dapat meminimalkan peran pendidik dan mengaktifkan peserta didik, mempermudah peserta didik untuk memahami materi dan memudahkan pelaksanaan pengajaran kepada peserta didik. Widjajanti, (2008) menambahkan bahwa worksheet akan efisien penggunaanya jika disusun secara sistematis serta memenuhi syarat didaktik, konstruksi dan syarat teknik.

ELPSA adalah pengembangan dari model pembelajaran ELPS yang dikembangkan sebelumnya oleh Liebeck pada tahun 1984. Model pembelajaran ELPS meliputi $\mathrm{E}$ (experience), L (language: mendeskripsikan experience), $\mathrm{P}$ (picture: menyajikan experience dalam bentuk gambar), dan $\mathrm{S}$ (symbol: mendefinisikan experience). Akan tetapi, ELPS tidak secara eksplisit menjelaskan penggunaan pengetahuan yang telah diperoleh. Di sisi lain, Program of International Student Assesment (PISA) dalam Thomson dan Buckley (2013) menyatakan bahwa keberhasilan suatu proses pembelajaran matematika tidak hanya berhenti pada kemampuan peserta didik memahami materi yang dipelajari. Akan tetapi, kemampuan untuk mengaplikasikan pengetahuan matematika yang mereka miliki ke dalam situasi lain juga harus diperhatikan. Bermula dari pemikiran tersebut, tim RIPPLE
(Research Institute for Professional Practice, Learning \& Education) yang diketuai oleh Prof. Tom Lowrie dari Charles Sturt University Australia mengembangkan ELPS dengan menambahkan satu elemen Application. Model pembelajaran yang dikembangkan oleh tim RIPPLE ini selanjutnya disebut dengan model pembelajaran ELPSA.

Wijaya (2014) menyatakan bahwa dalam ELPSA, pembelajaran dipandang sebagai proses aktif dimana mahasiswa mengkonstruksi sendiri dalam memahami sesuatu melalui proses berpikir dan interaksi sosial dengan orang lain. Elemen-elemen dalam ELPSA yang meliputi experience (pengalaman), language (bahasa), picture (gambar), symbol (simbol), dan application (aplikasi) saling berhubungan dan melengkapi satu sama lain tetapi tidak harus terjadi dalam urutan linier.

Lowrie dan Patahuddin (2015) menyatakan bahwa kerangka kerja ELPSA dapat membantu mahasiswa membangun pengetahuan dengan caranya sendiri dan melalui interaksi dengan teman yang lain. Penelitian tentang penggunaan ELPSA dalam pembelajaran telah banyak dilakukan diantaranya penelitian dari Arifin (2015) yang menyimpulkan bahwa kerangka kerja ELPSA dapat digunakan untuk menilai pemahaman siswa. Lebih lanjut, Johar dan Hajar (2016) dalam penelitiannya menyimpulkan bahwa komponen kerangka kerja ELPSA dapat membangun pemahaman mahasiswa dalam pembelajaran matematika.

Oleh karena itu, melalui elemen-elemen dalam ELPSA yang dituangkan dalam suatu worksheet diharapkan dapat menjadi suatu alternatif solusi meningkatkan pemahaman mahasiswa terhadap materi relasi rekurensi. Berdasarkan hal-hal yang telah diuraikan di atas, dirumuskan tujuan dalam penelitian ini yaitu untuk mengetahui rata-rata kemampuan 
pemahaman mahasiswa dalam pembelajaran relasi rekurensi menggunakan worksheet ELPSA melalui uji coba terbatas terhadap mahasiswa semester VIB Pendidikan Matematika Universitas Veteran Bangun Nusantara Sukoharjo.

\section{METODE}

Jenis penelitian ini adalah eksperimental semu (Quasi eksperimental) karena tidak memungkinkan untuk mengontrol semua variabel yang relevan dalam memperoleh informasi sebagai perkiraan informasi dari eksperimen yang sebenarnya (Budiyono, 2003). Cluster random sampling dilakukan terhadap mahasiswa semester VI Program Studi Pendidikan Matematika Universitas Veteran Bangun Nusantara Sukoharjo yang terbagi dalam 3 kelas. Dengan teknik sampling tersebut, diperoleh mahasiswa VIB sebagai kelas eksperimen yaitu kelas yang akan menggunakan worksheet ELPSA dalam pembelajaran relasi rekurensi.

Instrumen yang digunakan adalah worksheet ELPSA dan tes pengukur pemahaman mahasiswa terhadap materi relasi rekurensi. Kedua instrumen tersebut dinilai kelayakannya terlebih dahulu oleh dua validator di luar Universitas Veteran Bangun Nusantara Sukoharjo. Penilaian kelayakan instrumen didasarkan pada rubrik penilaian yang telah disusun sebelumnya. Rubrik penilaian worksheet ELPSA terdiri atas tiga aspek yaitu content (isi), language (bahasa), dan construction (konstruksi). Setiap indikator penilaian mempunyai rentang nilai 1 sampai dengan 5. Penilaian dari kedua validator kemudian dirata-rata sehingga diperoleh nilai rata-rata total validasi (RTV). Kategori kelayakan instrumen didasarkan pada kriteria yang dikemukakan oleh Khabibah $(2006,90)$ sebagai berikut
Tabel 2. Kriteria Kevalidan Instrumen

\begin{tabular}{ccc}
\hline Skor RTV & Kategori & Revisi \\
$4 \leq \mathrm{RTV} \leq 5$ & sangat valid & tidak perlu \\
$3 \leq \mathrm{RTV}<4$ & valid & revisi kecil \\
$2 \leq \mathrm{RTV}<3$ & kurang valid & revisi besar \\
$1 \leq \mathrm{RTV}<2$ & tidak valid & revisi besar \\
\hline RTV $:$ rata-rata total validasi &
\end{tabular}

Teknik analisis data yang digunakan adalah statistik uji t. Data yang akan dianalisis adalah nilai mahasiswa dalam tes pengukur pemahaman materi relasi rekurensi. Worksheet ELPSA dikatakan efektif dalam meningkatkan pemahaman mahasiswa terhadap materi relasi rekurensi jika dalam uji hipotesis dengan t-test diperoleh kesimpulan bahwa $\mu>76$ atau $\mathrm{H}_{0}$ ditolak. Indikator ini didasarkan pada kategori penilaian yang digunakan oleh Universitas Veteran Bangun Nusantara sebagai berikut:

Tabel 3. Kategori Penilaian di Univet Bantara Sukoharjo

\begin{tabular}{ccc}
\hline Skor Akhir & Nilai & Kategori \\
$\mathrm{X}>86$ & A & sangat memuaskan \\
$76<\mathrm{X} \leq 86$ & $\mathrm{~B}$ & memuaskan \\
$66<\mathrm{X} \leq 76$ & $\mathrm{C}$ & cukup memuaskan \\
$50<\mathrm{X} \leq 66$ & $\mathrm{D}$ & kurang memuaskan \\
$\mathrm{X} \leq 50$ & $\mathrm{E}$ & tidak memuaskan \\
\hline
\end{tabular}

Uji hipotesis dilakukan pada tingkat kesalahan $\alpha=5 \%$ dengan uji prasyarat normalitas. Metode Kolmogorov Smirnov dilakukan untuk menguji apakah sampel berasal dari populasi yang berdistribusi normal. Analisis data dilakukan dengan bantuan software SPSS 17.0 for windows. Pengambilan keputusan didasarkan pada nilai sig, (p). Jika sig. (p) lebih kecil dari $\alpha=5 \%$ maka $\mathrm{H}_{\mathrm{o}}$ ditolak.

\section{HASIL DAN PEMBAHASAN}

Terdapat tiga jenis worksheet ELPSA yang dikembangkan untuk pembelajaran relasi rekurensi pada penelitian ini. Worksheet 01 ELPSA memuat materi tentang pengertian relasi rekurensi, sedangkan worksheet 02 dan 
03 ELPSA memuat tentang penyelesaian relasi rekurensi dengan metode iterasi dan penyelesaian relasi rekurensi homogen linier koefisien konstan dengan persamaan karakteristik. Setiap worksheet terdiri atas: (1) cover (halaman sampul), (2) kompetensi dasar dan tujuan pembelajaran, (3) petunjuk penggunaan worksheet, (4) permasalahanpermasalahan yang merupakan elemen dari ELPSA yaitu experience (pengalaman), language (bahasa), picture (gambar), symbol (simbol), application (aplikasi). Sebagai contoh berikut dipaparkan worksheet 01 ELPSA yang telah dikembangkan dan digunakan dalam pembelajaran relasi rekurensi di Program Studi Pendidikan Matematika Universitas Veteran Bangun Nusantara Sukoharjo Tahun Akademik 2016/2017.

Pada tahap pertama ELPSA, mahasiswa dihadapi pada permasalahan experience (pengalaman) dalam permainan menara Hanoi yaitu bagaimana menentukan banyaknya langkah memindahkan kepingan-kepingan balok dari satu tiang ke tiang yang lain dimulai dari 1 keping, 2 keping, dst. Pada tahap ini, $82,14 \%$ mahasiswa mendapatkan pola barisan dari suatu percobaan bahwa untuk memindahkan sejumlah $(n+1)$ keping dapat dilakukan dengan memindahkan dua kali $n$ keping yang lebih kecil ditambah 1 keping yang paling besar. Pada tahap kedua language (bahasa), mahasiswa diarahkan untuk mengenal definisi relasi rekurensi, basis dan rekurens berdasarkan pengalaman yang diperoleh pada tahap 1. Untuk tahap ketiga picture (gambar), mahasiswa diminta menggambarkan langkahlangkah pemindahan kepingan-kepingan balok dari 1 kepingan, 2 kepingan, 3 kepingan, dan 4 kepingan seperti pada gambar 2 menggunakan bolpoin sesuai warna kepingan balok.

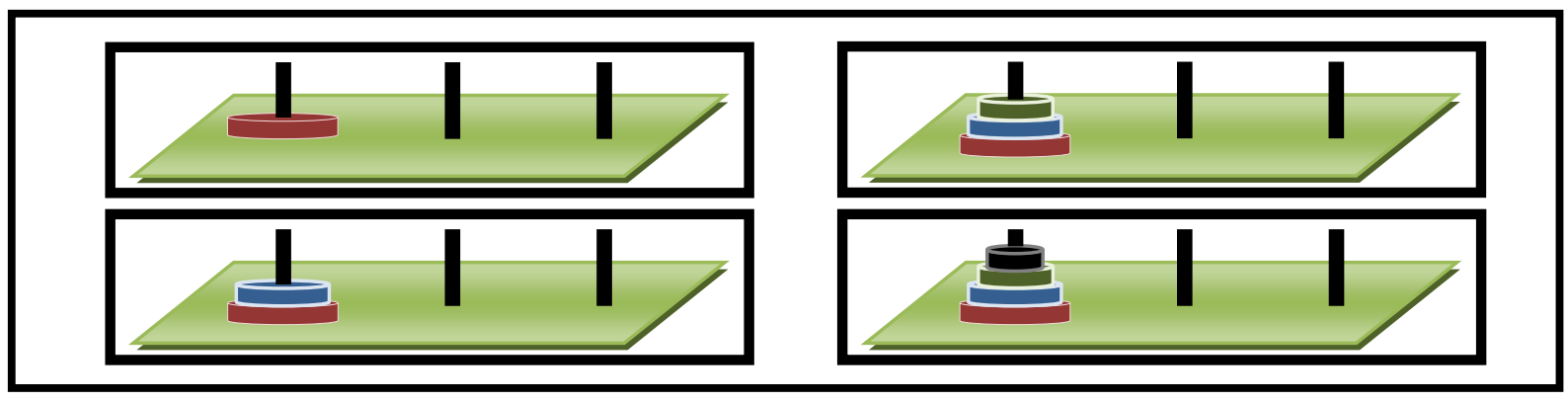

Gambar 2. Permasalahan 3 (Picture) pada worksheet 01 ELPSA

Pada tahap ketiga symbol (simbol), mahasiswa dikenalkan dengan simbol penulisan relasi rekurensi dan pada tahap terakhir application (aplikasi), mahasiswa diberikan persoalan yang berkaitan dengan relasi rekurensi yaitu perkembangbiakan hamster. Kegiatan pada tahap aplikasi ini akan menjadi tahap experience pada worksheet 02 ELPSA dan worksheet 03 ELPSA.

Selain worksheet ELPSA, disusun juga instrumen tes untuk mengetahui pemahaman mahasiswa mengenai materi relasi rekurensi.
Tes terdiri dari tiga soal uraian yang mewakili tiga materi yang diberikan dalam pembelajaran dengan worksheet ELPSA.

Draf worksheet ELPSA yang telah dikembangkan dan tes materi relasi rekurensi selanjutnya dinilai kelayakannya oleh dua orang validator. Hasil penilaian kedua validator terhadap kelayakan instrumen worksheet ELPSA dengan mengacu pada rubrik penilaian disajikan pada tabel 3. Sedangkan hasil penilaian kedua validator terhadap 
instrumen tes pemahaman materi relasi rekurensi disajikan pada tabel 4.

Tabel 3. Rangkuman Hasil Validasi Instrumen Worksheet ELPSA

\begin{tabular}{|c|c|c|}
\hline \multirow{2}{*}{ Aspek } & \multicolumn{2}{|c|}{ Rata-rata Penilaian } \\
\hline & validator 1 & validator 2 \\
\hline content & 3,7143 & 4,1429 \\
\hline bahasa & 4 & 3,75 \\
\hline konstruksi & 4 & 4 \\
\hline rata-rata total validitas & 3,9048 & 3,9643 \\
\hline $\begin{array}{l}\text { rata-rata penilaian } \\
\text { validator }\end{array}$ & \multicolumn{2}{|c|}{3,9345} \\
\hline kriteria kevalidan & \multicolumn{2}{|c|}{ VALID } \\
\hline
\end{tabular}

Tabel 4. Rangkuman Hasil Validasi Instrumen Tes Pemahaman Materi Relasi Rekurensi

\begin{tabular}{lcc}
\hline \multicolumn{1}{c}{ Aspek } & \multicolumn{2}{c}{ Rata-rata Penilaian } \\
& validator 1 & validator 2 \\
\hline content & 4,2 & 4,2 \\
bahasa & 4,25 & 5 \\
konstruksi & 4 & 4,5 \\
rata-rata total validitas & 4,15 & 4,5667 \\
rata-rata penilaian & \multicolumn{2}{c}{$\mathbf{4 , 3 5 8 3}$} \\
validator & \multicolumn{2}{c}{ VALID } \\
kriteria kevalidan & \multicolumn{2}{c}{. } \\
\hline
\end{tabular}

Dari tabel 3 diketahui bahwa rata-rata penilaian kedua validator sebesar 3,9345. Hal ini berarti, worksheet ELPSA valid dan hanya perlu revisi kecil. Catatan penilaian dari validator 1 adalah perlu ada penambahan tujuan pembelajaran relasi rekurensi pada bagian depan worksheet dengan tujuan agar mahasiswa mempunyai gambaran tentang penggunaan relasi rekurensi. Sedangkan catatan penilaian validator 2 , pada tahap application (aplikasi) worksheet ELPSA 01 perlu ada modifikasi soal dari barisan Fibonacci. Berdasarkan catatan penilaian kedua validator tersebut, maka dilakukan revisi kecil terhadap worksheet ELPSA sesuai dengan saran validator. Dari tabel 4, hasil penilaian kedua validator terhadap tes materi relasi rekurensi disimpulkan bahwa instrumen tes sangat valid. dan tidak ada catatan dari kedua validator sehingga tidak ada revisi terhadap instrumen tersebut.
Eksperimen dilakukan menggunakan instrumen yang telah divalidasi. Pelaksanaan pembelajaran relasi rekurensi menggunakan worksheet ELPSA berjalan dengan efektif. Pembelajaran dilakukan sebanyak tiga pertemuan. Menurut pengamatan peneliti selama eksperimen dilakukan, mahasiswa sangat aktif dalam pembelajaran, banyak ide-ide baru yang muncul selama menyelesaikan worksheet ELPSA. Hal ini berarti, worksheet ELPSA dapat meningkatkan kemandirian dan kemampuan berpikir kritis mahasiswa. Pada akhir pembelajaran, mahasiswa diberi tes untuk mengetahui kemampuan memahami materi relasi rekurensi. Deskripsi data hasil tes tersebut disajikan pada tabel 5.

Tabel 5. Deskripsi data hasil tes pemahaman relasi rekurensi

\begin{tabular}{ccccc}
\hline $\mathbf{N}$ & $\overline{\mathbf{X}}$ & $\boldsymbol{\sigma}^{\mathbf{2}}$ & $\mathbf{X}_{\min }$ & $\mathbf{X}_{\max }$ \\
\hline 28 & 77,46 & 11,813 & 69 & 84 \\
\hline
\end{tabular}

Analisis data dengan one tailed t-test dilakukan pada tingkat kesalahan $\alpha=5 \%$ terhadap data hasil tes tersebut. Berdasarkan uji normalitas, disimpulkan bahwa sampel berasal dari populasi berdistribusi normal. Lebih jelas hasil uji normalitas disajikan pada Tabel 6.

Tabel 6. Hasil Uji Normalitas Data Hasil Tes Relasi Rekurensi

\begin{tabular}{cccc}
\hline Lhitung & sig. (p) & Keputusan & Kesimpulan \\
\hline 0,161 & 0,061 & $\begin{array}{c}\mathrm{H}_{\mathrm{o}} \text { tidak } \\
\text { ditolak }\end{array}$ & Normal \\
\hline
\end{tabular}

Oleh karena itu, analisis data statistik terhadap data hasil tes relasi rekurensi dapat dilakukan menggunakan one tailed t-test. Hasil uji hipotesis dengan one tailed t-test disajikan pada Tabel 7.

Tabel 7. Hasil uji hipotesis data hasil tes relasi rekurensi

\begin{tabular}{ccccc}
\hline $\mathbf{t}_{\text {hitung }}$ & sig. (p) & $\begin{array}{c}\text { Mean } \\
\text { Difference }\end{array}$ & Keputusan & Kesimpulan \\
\hline 2,254 & 0,032 & 1,464 & $\mathrm{H}_{\mathrm{o}}$ ditolak & $\mu>76$ \\
\hline
\end{tabular}


Berdasarkan tabel 6, diketahui sig. $(\mathrm{p})=$ $0,061>0,05$ maka $\mathrm{H}_{0}$ tidak ditolak atau asumsi normalitas dipenuhi. Dari tabel 7, sig. (2-tailed) $=0,032<0,05$ maka $\mathrm{H}_{0}$ ditolak dan berdasarkan nilai mean difference $=1,464$ yang bernilai positif, maka dapat disimpulkan bahwa rata-rata nilai tes relasi rekurensi kelas B lebih besar dari 76. Oleh karena itu, dapat dikatakan bahwa penggunaan worksheet ELPSA dapat menghasilkan rata-rata pemahaman mahasiswa melebihi batas minimal yang ditetapkan Universitas untuk mendapatkan nilai memuaskan.

Pembelajaran dengan worksheet ELPSA mampu mengaktifkan mahasiswa, membantu mahasiswa dalam memahami konsep relasi rekurensi dengan caranya sendiri melalui pengalaman yang diperoleh melalui tahapan ELPSA. Hal ini sependapat dengan Anggraini (2016) bahwa keterampilan proses dalam pembelajaran yang mengedepankan pengalaman personal untuk meningkatkan kreativitas peserta didik dianggap perlu. Hasil penelitian sebelumnya menyatakan bahwa keikutsertaan siswa dalam proses belajar dapat meningkatkan aktivitas belajar yang optimal sehingga dapat meningkatkan hasil belajar (Hansah, 2013). Penelitian lain memberikan hasil bahwa kerangka kerja ELPSA dapat membangun pemahaman siswa tentang matematika. Proses pembelajaran matematika tidak secara langsung berkaitan dengan simbol-simbol seperti yang banyak terjadi dalam pembelajaran di Indonesia (Lowrie \& Patahuddin, 2015). Berdasarkan hasil dari kedua penelitian tersebut terlihat bahwa pembelajaran

\section{DAFTAR PUSTAKA}

Anggraini, R., Wahyuni, S., Lesmono, A.D. (2016). Pengembangan Lembar Kerja Siswa (LKS) Berbasis Keterampilan Proses di SMAN 4 Jember. Jurnal Pembelajaran Fisika. 4(4). 350-356.

Arifin. 2015. Lesson Plan Berbasis Kerangka Kerja ELPSA untuk Membangun dengan menggunakan worksheet yang disusun berdasarkan kerangka kerja ELPSA dapat membantu mahasiswa meningkatkan pemahamannya dibandingkan pembelajaran langsung.

\section{SIMPULAN}

Berdasarkan hasil analisis data dan pembahasan pada bab sebelumnya, diperoleh kesimpulan bahwa penggunaan worksheet ELPSA dapat menghasilkan rata-rata pemahaman mahasiswa tentang relasi rekurensi melebihi batas minimal yang ditetapkan Universitas untuk mendapatkan nilai memuaskan.

Adapun beberapa saran yang dapat disampaikan peneliti berdasarkan kesimpulan yang sudah ada adalah sebagai berikut: 1) hendaknya penggunaan worksheet ELPSA didukung dengan model pembelajaran lain dan diupayakan penggunaannya berbasis ICT agar lebih menarik; 2) worksheet ELPSA akan dapat digunakan sebagai alternatif pembelajaran yang sangat efektif jika dosen juga meninjau faktor-faktor lain yang mungkin berpengaruh terhadap prestasi belajar mahasiswa; 3) efektivitas worksheet ELPSA dapat dikaji untuk mata kuliah yang lain dan dapat dikaji pula pada subyek penelitian yang berbeda; 4) hendaknya pembelajaran khususnya di Perguruan Tinggi lebih menekankan pada aplikasi dan terapan untuk menyiapkan sumber daya manusia yang berkualitas.

Pemahaman Konsep Penjumlahan dan Pengurangan Bilangan Bulat pada Siswa. Jurnal Kependidikan. 14(1). 11-21.

Budiyono, (2003). Metodologi Penelitian Pendidikan. Surakarta: Sebelas Maret University Press. 
Hansah, F., Yulianti, D., Sugianto. (2013). Pembelajaran Fisika Menggunakan Better Teaching and Learning Berketerampilan Proses Untuk Meningkatkan Aktivitas Belajar Siswa di SMP. Unnes Physec Education Journal. 2(3). 37-42.

Johar, Rahmah \& Hajar, Siti. (2016). Implementation of ELPSA Framework in Teaching Integral Using Technology. International Journal of Science and Apllied Technology, 1(1). 15-21.

Khabibah, Siti. (2006). Pengembangan Perangkat Pembelajaran Matematika Dengan Soal Terbuka Untuk Meningkatkan Kreatifitas Siswa Sekolah Dasar. Disertasi Program Pascasarjana UNESA.

Lowrie. T., Patahuddin, S.M., (2015). ELPSAKerangka Kerja Merancang Pembelajaran Matematika. Jurnal Didaktik Matematika, 2(1), 94-108.

Lowrie. T., Patahuddin, S.M., (2015). ELPSA as a Lesson Design Framework. Jurnal IndoMS JME, 6(2), 1-15.
Prastowo, Andi. (2013). Panduan Kreatif Membuat bahan Ajar Inovatif. Yogyakarta: DIVA Press.

Thomson, S., De Bortoli, L., \& Buckley, S. (2013). PISA 2012: How Australia measures up. Victoria, Australia: Australian Council for Educational Research.

Usman. Model PBI untuk Mengembangkan Pemahaman Mahasiswa dalam Memecahkan Masalah tentang Integral Tentu. Jurnal Peluang. 1(2). 1-11.

Wijaya, Adi. (2014). Pengenalan Desain Pembelajaran ELPSA (experiences, language, pictures, symbols, application). Artikel Pusat Pengembangan dan Pemberdayaan Pendidik dan Tenaga Kependidikan (PPPPTK) Matematika.

Zahro, U.L., Serevina, V., Astra, I.M. (2017). Pengembangan Lembar Kerja Siswa (LKS) Fisika dengan Menggunakan Strategi Realting, Experiencing, Applying, Cooperating, Transferring (REACT) Berbasis Karakter Pada Pokok Bahasan Hukum Newton. Jurnal Wahana Pendidikan Fisika. 2(1). 63-68. 